DOI 10.18699/SBB-2020-89

\title{
Ассоциация G1181C полиморфизма гена TNFRS11B с риском развития ишемической болезни сердца у жителей Республики Адыгея
}

\author{
Шумилов Д.*, Тугуз А., Татаркова Е. \\ Адыгейский государственный университет, НИИ Комплексных проблем, Майкоп, Россия \\ *e-mail:dmi6277@yandex.ru
}

Ключевые слова: атеросклероз, ишемическая болезнь сердца, фактор некроза опухоли

Мотивация и цель: По оценкам ВОЗ, основными причинами смертности и инвалидизации населения мира являются болезни системы кровообращения. При этом ежегодные потери от ишемической болезни сердца, развившейся на фоне атеросклеротического поражения коронарных сосудов, составляют более 7 миллионов человек. В России сохраняется самый высокий среди европейских стран уровень преждевременной смертности от ИБС, при этом само заболевание занимает главенствующую позицию. В мировых популяциях определение риска развития ИБС связывают с SNP в гене рецептора TNF-a. TNF-a - представитель семейства провоспалительных цитокинов с широким спектром активности. TNF связывается с двумя рецепторами, TNFR1 TNFR2, которые являются ключевыми медиаторами передачи сигналов от TNF.

Meтоды и алгоритмы: В исследование включен 61 житель республики Адыгея; в том числе: неродственные здоровые доноры $(n=16)$ и больные $(n=41)$ - пациенты кардиологического отделения Адыгейской республиканской клинической больницы (АРКБ) с диагнозом ИБС, подтвержденным инструментальными методами. Соответствие распределений SNP в обследованных группах больных и доноров проводили с использованием критерия $\chi 2$ (хи-квадрата) для таблиц сопряженности $2 \times 2$ с поправкой Йейтса на непрерывность, расчетом отношения шансов (Odds-Ration, или OR), 95\% доверительного интервала (95\% ДИ) и достоверности различий при $\mathrm{P} \leq 0,05$. Статистические расчеты проведены с использованием пакета прикладных программ SPSS Statistics 17.0 (Inc., Chicago, USA) и Office Excel 2016 (Microsoft).

Результаты: В ходе генетического анализа экспериментально установлено, что у жителей РА, носителей патологического C1181C генотипа и C1181 мутантной аллели риск развития ишемической болезни сердца повышается в 8 раз $(\chi 2=22,98 ; p<0,001 ; \mathrm{OR}=8)$.

Заключение и доступность: У жителей РА, с ИБС ассоциирован C1181C патологический генотип и $1181 C$ мутантная аллель гена TNFRSF11B $(\chi 2=22,98 ; \mathrm{p}<0,001)$.

Список литературь

1. Wang, M. et al. TNFRSF11B polymorphisms predict poor outcome after large artery atherosclerosis stroke. Gene. 2020. C. 144617.

2. Tong X. et al. Suppression of AMP-activated protein kinase reverses osteoprotegerin-induced inhibition of osteoclast differentiation by reducing autophagy. Cell Proliferation. 2019. P. e12714.

3. Kosmopoulos M. et al. The Emerging Role of Bone Markers in Diagnosis and Risk Stratification of Patients With Coronary Artery Disease. Angiol. 2019. V. 70. №. 8. P. 690-700. 